\title{
Criminal Responsibility of Criminals Defamation on Advocate Name
}

\author{
Bambang Lasimin Arek ${ }^{*}$ and Umar Ma'ruf ${ }^{* *}$ \\ *) Student of Master of Law, Faculty of Law, Universitas Islam Sultan Agung \\ Semarang, Indonesia, E-mail: bambang.l.arek@gmail.com \\ ${ }^{* *}$ Faculty of Law Universitas Islam Sultan Agung
}

\begin{abstract}
The purpose of this research is to know and understand the legal responsibility of the criminal defamation against lawyers according to Islamic criminal law, to know and understand the legal responsibility of the criminal defamation against lawyers according to Indonesian criminal law as well as to know, understand and analyze the legal accountability of the perpetrators criminal defamation against advocates at the Law Supremacy \& Associate law office in Police Report Number: LP / B / 115B / XI / 2019 / Jabar according to Islamic criminal law and Indonesian criminal law. The approach method used in this research is normative juridical. The research specification used in this research is descriptive analytical. The theory used in analyzing the above problems is the rule of law theory, the theory of legal certainty and the theory of criminal responsibility in Islamic law. The conclusion of this study is that legal responsibility for the perpetrators of criminal defamation against advocates according to Islamic law is a Ta'zir sentence in the form of a limited prison sentence, where the length of the sentence is handed over to Ulil Amri who examines the case, while according to Indonesian criminal law it is a prison sentence and fines. Legal accountability for perpetrators of criminal defamation against advocates in the Police Report Number: LP / B / 115B / XI / 2019 / Jabar, according to Islamic law, is punishable by Ta'zir in the form of limited prison. Meanwhile, according to Indonesian criminal law, the actions of suspects are subject to imprisonment and a fine, in accordance with the provisions of Article 311 paragraph (1) and Article 315 of the Criminal Code.
\end{abstract}

Keywords: Legal Accountability; Defamation; Advocates; Islamic Criminal Law; Indonesian Criminal Law.

\section{Introduction}

Article 1 number 1 of Act No. 18 of 2003 concerning Advocates (hereinafter referred to as the Advocate Law), states that an advocate is a person whose profession is to provide legal services, both inside and outside the court who meets the requirements based on the provisions of this law. Advocate is a noble profession (officium nobile). This predicate is given because of the "trust" aspect of the client that he carries out to defend and fight for their rights in a predetermined forum. ${ }^{1}$

Advocates can be a mediator for parties in dispute about a case, whether related to criminal cases, civil cases, or cases of state administration. Advocates can also become facilitators in seeking the truth and upholding justice to defend human rights and provide legal defense that is free and independent.

\footnotetext{
${ }^{1}$ Panggaribuan, Luhut M. P. (1996). Advokat dan Contemp of Court Satu Proses di Dewan Kehomatan Profesi, Jakarta: Djambatan. p.1.
} 
The role played by a defender is as a guard (bodyguard) of the power of the court, in this case the defense has the duty to ensure that legal officials do not commit abuses that harm the rights of the suspect or defendant. ${ }^{2}$

The existence of advocates and their regulation in Indonesia has existed for about a century and a half ago, however recognition of advocates is not regulated in a regulation like law, but only sporadically stated in articles of statutory regulations issued since the colonial era. Netherlands. ${ }^{3}$

Act No. 18 of 2003 concerning Advocates (hereinafter referred to as the Advocate Law) has regulated the principles or basis for carrying out the duties of the advocate profession, particularly in its role in upholding justice and realizing state principles based on law, this can be seen from the provisions of Article 15 of the Law. Advocates, stating that: "Advocates are free in carrying out their professional duties to defend cases for which they are responsible by sticking to the professional code of ethics and laws and regulations".

Article 15 of the Advocate Law provides an understanding that advocates are free in carrying out their duties, namely to defend legally, both inside and outside the court without any pressure, threats, obstacles, without fear or treatment that degrading the dignity of the advocate profession.

In fact, there are still advocates who, in carrying out their duties, receive threats and intimidation, as experienced by lawyers at the Law Supremacy \& Associate law office which is located at St. Mayor Abdurahman, Kubang Jaya No 07, RT 04 RW 05 Sumedang Regency, as stated in the Report. Police Number: LP / B / 115B / XI / 2019 / West Java, because they felt they had been threatened and intimidated in the forum.

The legal issues that will be examined in this journal are: What is the legal accountability of the criminal defamation against advocates according to Islamic criminal law, How is the legal responsibility for the criminal defamation against lawyers according to Indonesian criminal law, and How is the legal accountability analysis of the perpetrators criminal defamation against advocates at the Law Supremacy \& Associate law office in Police Report Number: LP / B / 115B / XI / 2019 / Jabar according to Islamic criminal law and Indonesian criminal law.

\section{Research methods}

The approach method used in this research is normative juridical. Normative juridical research is research conducted by examining library materials (secondary data), which are related to legal issues and norms that apply in accordance with the thesis. ${ }^{4}$ This legal research is a legal research that is carried out with the aim of discovering the principles or doctrines of positive law that apply. This type of research is commonly referred to as dogmatic studies or what is known as doctrinal research. ${ }^{5}$

\footnotetext{
${ }^{2}$ Rahardjo, Satjipto.(1976). Hukum Masyarakat dan Pembangunan, Bandung: Alumni. p.104.

${ }^{3}$ Langgeng, Setyo. "Peran Advokat Sebagai Penegak Hukum dalam Mendukung Terwujudnya Sistem Peradilan Pidana Terpadu dalam Penegakan Hukum Pidana di Indonesia", Jurnal Daulat Hukum, Volume 1 Nomor 1,Program Magister(S2) Ilmu Hukum Unissula, Semarang, March 2018, p.143.

${ }^{4}$ Ediwarman. (2015). Monograf Metodologi Penelitian Hukum, Medan : Sofmedia. p.25.

${ }^{5}$ Sugono, Bambang. (1996). Metodologi Penelitian Hukum, Jakarta: PT. Raja Grafindo Persada. p.86.
} 
The research specification used in this research is descriptive analytical, that is, by describing the applicable laws and regulations associated with legal theories and practice of positive law enforcement related to the problem. ${ }^{6}$

The type of data used by the author in this study is secondary data. Secondary data is data obtained by researchers from library research and documentation, which is the result of research and processing of others, which is already available in the form of books or documentation which are usually provided in public libraries or private libraries. $^{7}$ The secondary data includes primary legal materials, secondary legal materials and tertiary legal materials. ${ }^{8}$

The data analysis used by researchers in this thesis is qualitative data analysis, where the researcher provides an overview of the legal accountability of the criminal defamation against lawyers according to Islamic criminal law and Indonesian criminal law, as in Police Report Number: LP / B / 115B / XI / 2019 / West Java.

\section{Result and Discussion}

\subsection{The Legal Accountability of Perpetrators of Defamation Against Advocates According to Islamic Criminal Law}

Legal accountability (criminal) in Islamic law is enforced on three grounds. First, doing actions that are prohibited by the text. Second, the act was done of their own accord. Third, the perpetrator knows the consequences of the actions he has done and can bear all the consequences.

The criminal act of defamation against advocates in Islamic criminal law can be categorized as a minor crime punishable by $T a^{\prime}$ zir. Defamation of an advocate only offends the advocate (someone) feelings and does not hurt the body member of the lawyer, because this act only hurts the feelings of the insulted lawyer's heart. This act in Islamic criminal law qualifies as a tahmah Ta'zir, that is, an act that is punishable by one or several $T a^{\prime} z i r$ punishments.

Jarimah Ta'zir is divided into two types, namely Jarimah Ta'zir which offends on the rights of Allah and Jarimah Ta'zir which pertains to individual rights, in this case the criminal act of defamation against advocates belongs to Jarimah $\mathrm{Ta}^{\prime}$ zir which violates individual rights, where the punishment is which can be imposed on the perpetrator is a prison sentence.

Prison sentence according to syara', is not detaining the perpetrator of a criminal act in a narrow place, but is carried out in a house, mosque or other place, while the prison sentence according to Islamic law is divided into two types. The first type, is a limited prison sentence, where the length of time is strictly limited and is based on the perpetrator and the type of finger he does. The second type is unlimited imprisonment

\footnotetext{
${ }^{6}$ Soemitro, Ronny Hanitijo. (1990). Metode Penelitian Hukum dan Jurimetri, Jakarta: PT. Ghalia Indonesia. p.97.

${ }^{7}$ Hadikusuma, Hilman. (1995). Metode Pembuatan Kertas atau Skripsi Ilmu Hukum, Bandung : Mandar Maju. p.65.

${ }^{8}$ Soerjono Soekanto. (2011). Penelitian Hukum Normatif (Suatu Tinjauan Singkat), Jakarta: Rajawali Pers. p.13.
} 
(life), where this punishment is not limited in time, but continues until the person being sentenced dies or the perpetrator repents.

Legal (criminal) responsibility can be imposed on the perpetrator of criminal defamation against advocates, if the elements of criminal responsibility in Islamic law have been fulfilled in the perpetrator. These elements include actions prohibited by the text, actions carried out on their own will and the perpetrator knows the consequences of his actions and can bear the consequences of his actions. With the fulfillment of these elements of responsibility, the perpetrator can be sentenced to a limited prison sentence, where the duration of this sentence is left to the judge who examines the case.

\subsection{The Legal Accountability of Perpetrators of Defamation Against Advocates According to Indonesian Criminal Law}

Accountability in criminal law essentially discusses whether or not the perpetrator of a criminal act can be convicted and adheres to the principle of geen straft zonder schuld, that is, there is no crime without error. Liability for criminal law can be brought to a person if that person has committed a criminal act, is able to be responsible, deliberately or by negligence and there is no excuse. ${ }^{9}$ There are several ways to formulate the elements of a criminal act. There are 4 (four) types of methods in formulating criminal acts, consisting of:

- The most common way is to explain the contents of a criminal act, from which the information can be translated into the elements of a punishable act, such as Articles 279, 281, 286, 242 and so on of the Criminal Code;

- By explaining (providing) the elements and providing characteristics (qualifications) such as falsification of Article 263 of the Criminal Code, theft of Article 362 of the Criminal Code, embezzlement of Article 372 of the Criminal Code and fraud of Article 378 of the Criminal Code;

- The method that is rarely used is to only provide qualifications such as persecution of Article 351 of the Criminal Code, and murder of Article 338 of the Criminal Code; and

- Sometimes the law only formulates the threat of punishment for regulations that are still to be made later, for example Article 521 and Article 121 paragraph (1) of the Criminal Code. ${ }^{10}$

A perpetrator of a criminal act, in order to be sentenced to a criminal sentence, must fulfill the elements of his criminal responsibility, including acts prohibited by statutory regulations, the ability to be responsible, an error in the form of deliberate action or negligence, justification and excuse.

Regulations related to defamation of advocates, in the Criminal Code can be seen in Article 310, Article 311 and Article 315. If you pay attention to the provisions of Article

\footnotetext{
${ }^{9}$ Hamzah, Muhammad Dani. "Penegakan Hukum Pada Kasus Tindak Pidana Kecelakaan Lalu Lintas Yang Menyebabkan Hilangnya Nyawa Orang", Jurnal Daulat Hukum, Program Pascasarjana Unissula, Semarang, Volume I, Nomor I, March 2018. p.46.

${ }^{10}$ Susanto, Eko Adi. "Pertanggungjawaban Pidana Yang Memakai Surat Palsu Ditinjau dari Pasal 263 ayat (2) KUH Pidana", Jurnal Daulat Hukum, Program Magister (S2) Ilmu Hukum Fakultas Hukum Unissula, Semarang, Volume I, Nomor I, March 2018. p.4.
} 
310 paragraph (1). The offensive act in Article 310 paragraph (1) of the Criminal Code, is not physical because what is being attacked (the object) is not physical but a feeling of respect and feelings about a person's good name. Meanwhile, the elements contained in Article 310 paragraph (2) of the Criminal Code include all objective and subjective elements in Article 310 paragraph (1) of the Criminal Code, the element of accusing them of committing an act by means of writing or pictures by broadcasting, showing and pasting.

The next provision, namely Article 311 paragraph (1) of the Criminal Code, where the elements include all the elements contained in Article 310 paragraph (1) and (2), the perpetrator element is allowed to prove what he is accused of is true, the perpetrator element cannot prove the truth of his accusation and what element of his accusation is contrary to what he knows. Actions regulated in this article are insulting or insulting by letter / writing but the perpetrator is allowed to prove the act.

The actions of the perpetrators as formulated in Article 311 paragraph (1) of the Criminal Code, are not crimes that stand alone, apart from crimes of defamation and defamation, but are specific forms of defamation, so that for the occurrence of these acts it requires pollution or pollution in writing. Permission to prove the truth of what is accused by the perpetrator is stipulated by the judge, that is, if the act is committed for the public interest, the act is committed to defend oneself and the accused is a civil servant in carrying out his / her duties

Actions as regulated in Article 310 paragraph (1) and paragraph (2) of the Criminal Code, do not include insulting or insulting by writing, if the accusation is made to defend the public interest or is forced to defend oneself. In this case, the judge will then conduct an examination whether it is true that the insult has been committed by the defendant because it is for public interest or self-defense, if the defendant asks to be examined (Article 312 of the Criminal Code). If the matter of defense cannot be considered by the judge, while in the examination it turns out that what the defendant accuses is not true, then the defendant is not blamed for insulting, but will be subject to Article 311 of the Criminal Code (defamation).

Minor humiliation is regulated in Article 315 of the Criminal Code. As it is known that defilement is a part of humiliation, so is light humiliation, so that the actions and objects of defilement are the same as the deeds and objects of insult. In defamation or written defamation there is an element of deliberation, so in light insult, this element is also present in the mind of the doer, although in light insults there is no defilement or defilement in writing. There are similarities and differences between deliberate light humiliation and deliberate defamation or defamation in writing.

Legal responsibility for the perpetrators of criminal defamation against advocates according to Indonesian criminal law, if you pay attention to the description above, then if the element of criminal responsibility has been fulfilled in the perpetrator, then the perpetrator can be subject to criminal penalties as regulated in Article 310, Article 311 and Article 315 of the Criminal Code, namely in the form of imprisonment, imprisonment and fines.

\subsection{Analysis of the Legal Accountability of Perpetrators of Defamation Crime Against Advocates at Law Supremacy \& Associate Law Firms}


In general, criminal law functions to regulate the life of the community so that public order can be created and maintained. Humans, in their efforts to meet the different needs and interests of their lives, sometimes experience conflicts with one another, which can cause harm or interfere with the interests of others. In order not to cause harm and interfere with the interests of other people in an effort to fulfill their daily needs, the law provides rules that limit human actions, so that they cannot do what they want. ${ }^{11}$

Sources of Indonesian criminal law, including:

- In writing, namely the Criminal Code (along with laws amending and adding to it), laws outside the Criminal Code, criminal provisions in non-criminal regulations;

- It is not written, namely the customary criminal law for several regions must also be taken into account;

- Memorie van toelicting (MvT), namely the memory of the explanation of the Criminal Code. This MvT is an explanation of the criminal law plan, which was submitted by the Minister of Justice (Netherlands) together with the proposed law to the Dutch parliament (twedee kamer). This bill was later (in 1881) passed into law and finally on September 1, 1886 it came into effect. ${ }^{12}$

Criminal is regulated in Chapter II, Articles 10-43 of the Criminal Code. Based on Article 10 of the Criminal Code are:

- The main penalties consist of capital punishment, imprisonment, imprisonment, fines and imprisonment. The closure penalty is a new type of crime because it is issued under Act No. 20 of 1946 concerning the Cover Penalty; and

- Additional penalties consisting of revocation of certain rights, confiscation of certain goods and announcement of a judge's decision. ${ }^{13}$

A person can be found guilty and commits a criminal act, if he meets the requirements which are the basis for his criminal responsibility. The actions of Heri Purnama and Beny Suhendra (hereinafter referred to as the suspects) as in the Police Report Number: LP / B / 115B / XI / 2019 / Jabar, are acts that are contrary to the Koran and al-Hadith, where the suspect has mentioned the legal counsel of Ucu Syamsul Ma'arif as "belegug (stupid) lawyer", "loan shark lawyer" and "debt collector lawyer". The suspect's actions can clearly reduce human dignity.

The suspects committed their actions on their own accord, namely mentioning the attorney of Ucu Syamsul Ma'arif without coercion or pressure from other parties and as a Muslim, of course the suspects know about the prohibitions on his actions, as regulated in the Koran and described in al-hadith above, but the suspects still did their actions. The suspects are also well aware that the consequences of their actions, namely by calling the attorney of Ucu Syamsul Ma'arif a "belegug (stupid) lawyer",

\footnotetext{
${ }^{11}$ Hardiansyah, Aan. "Tindak Pidana Kekerasan dalam Proses Belajar Mengajar Ditinjau dari Perspektif Hukum Pidana dan Undang-Undang Nomor 14 Tahun 2005 tentang Guru dan Dosen", Jurnal Daulat Hukum, Program Magister (S2) Ilmu Hukum Fakultas Hukum Unissula, Semarang, Volume I, Nomor 1, March 2018. p.91.

12 Maerani, Ira Alia. (2018). Hukum Pidana dan Pidana Mati, Semarang : Unissula Press. p.60, dikutip dari Sudarto, 2009, Hukum Pidana I, Cetakan Ketiga, Semarang : Fakultas Hukum UNDIP. p.30.

13 Siregar, Hulman. "Rumusan Pidana dan Pemidanaan Tindak Pidana Korupsi yang Merugikan Keuangan Negara serta Permasalahan dalam Penerapannya", Jurnal Daulat Hukum, Program Magister (S2) Ilmu Hukum Fakultas Hukum Unissula, Semarang, Volume 1, Nomor 1, March 2018. p.132.
} 
"loan shark lawyer" and "debt collector attorney", could undermine the dignity of the attorney from Ucu Syamsul Ma'arif, who in fact is an advocate and legal consultant.

The fulfillment of the three conditions which constitute the basis of criminal responsibility in the actions of the suspects, then as a consequence the suspects can be sentenced. Based on the perspective of Islamic law, the suspect's actions, namely calling Ucu Syamsul Ma'arif's attorney "belegug (stupid) lawyer", "loan shark attorney" and "debt collector attorney", constitute a violation involving human dignity. This act only offends Ucu's attorney Syamsul Ma'arif and does not injure his limbs, so that the punishment can be subject to Ta'zir punishment, which is in the form of a limited prison sentence, where for the length of this sentence is left to the judge who examines the cases of the suspects.

The actions of the suspects, in Indonesian criminal law, also violate the provisions of Article 311 paragraph (1) and Article 315 of the Criminal Code, namely defamation in the form of insult. These actions were carried out by the suspects by calling Ucu's attorney Syamsul Ma'arif a "belegug (stupid) lawyer", "loan shark lawyer", and "debt collector lawyer", thus the elements as stated in the two articles have been fulfilled in the actions of the suspects.

The fulfillment of the element of criminal responsibility in the actions of the suspects, as described above, has consequences for the suspects, namely that the suspects can be sentenced to criminal penalties in accordance with the prevailing laws and regulations. The criminal penalties that can be imposed on the suspects are in the form of imprisonment or fines, as regulated in Article 311 paragraph (1) and Article 315 of the Criminal Code.

\section{Closing}

Legal accountability for perpetrators of criminal defamation against advocates according to Islamic law is a $T a^{\prime}$ zir sentence in the form of a limited prison sentence, where the length of the sentence is left to Ulil Amri (judge) who examines the case. The imposition of the sentence is based on the fulfillment of the elements of criminal responsibility, including the existence of an act that is prohibited by the texts, the act is committed on his own will and the perpetrator knows the consequences of the act and can bear the consequences of his actions

Legal liability for perpetrators of criminal defamation against advocates according to Indonesian criminal law is a prison sentence and a fine in accordance with the prevailing laws and regulations. Sentencing of the perpetrator can be imposed if the elements of criminal responsibility have been fulfilled, including the existence of acts that are prohibited by law, the existence of the ability of the perpetrator to be responsible, the reasons for justification and reasons for forgiveness.

Legal accountability for perpetrators of criminal defamation against advocates at the Law Supremacy \& Associate Law Office in Police Reports Number: LP / B / 115B / XI / 2019 / Jabar, according to Islamic law is with a Ta'zir penalty in the form of a limited prison for a long time to be handed over on Amri's ulil who examined the case. Meanwhile, according to Indonesian criminal law, the actions of the suspects are subject to imprisonment and fines, in accordance with the provisions of Article 311 paragraph (1) and Article 315 of the Criminal Code because in addition to the elements 
of the two articles have been fulfilled, there is also the ability to be responsible for the suspects and the absence of justification and excuse for the actions of the suspects.

It is necessary to improve people's knowledge and understanding of the values in Islamic teachings that fellow humans who have the same position in the eyes of Allah SWT can respect and respect each other so that defamation does not arise. The public needs to re-understand the meaning of freedom in opinion, this means that freedom of opinion should not be detrimental, because if it harms others by defaming someone, then this freedom has violated statutory regulations and can be subject to criminal penalties. It is important to give maximum sanctions to the suspects who have defamed an advocate, this is because that the suspect's actions, not only degrade the dignity of a defamed advocate, but also the reputation of the advocate profession as a whole.

\section{References}

Journals:

[1] Hamzah, Muhammad Dani. "Penegakan Hukum Pada Kasus Tindak Pidana Kecelakaan Lalu Lintas Yang Menyebabkan Hilangnya Nyawa Orang", Jurnal Daulat Hukum, Program Pascasarjana Unissula, Semarang, Volume I, Nomor I, March 2018.

[2] Hardiansyah, Aan. "Tindak Pidana Kekerasan dalam Proses Belajar Mengajar Ditinjau dari Perspektif Hukum Pidana dan Undang-Undang Nomor 14 Tahun 2005 tentang Guru dan Dosen", Jurnal Daulat Hukum, Program Magister (S2) IImu Hukum Fakultas Hukum Unissula, Semarang, Volume I, Nomor 1, March 2018.

[3] Langgeng, Setyo. "Peran Advokat Sebagai Penegak Hukum dalam Mendukung Terwujudnya Sistem Peradilan Pidana Terpadu dalam Penegakan Hukum Pidana di Indonesia", Jurnal Daulat Hukum, Volume 1 Nomor 1,Program Magister(S2) IImu Hukum Unissula, Semarang, March 2018.

[4] Maerani, Ira Alia. (2018). Hukum Pidana dan Pidana Mati, Semarang : Unissula Press. p.60, dikutip dari Sudarto, 2009, Hukum Pidana I, Cetakan Ketiga, Semarang : Fakultas Hukum UNDIP.

[5] Siregar, Hulman. "Rumusan Pidana dan Pemidanaan Tindak Pidana Korupsi yang Merugikan Keuangan Negara serta Permasalahan dalam Penerapannya", Jurnal Daulat Hukum, Program Magister (S2) Ilmu Hukum Fakultas Hukum Unissula, Semarang, Volume 1, Nomor 1, March 2018.

[6] Susanto, Eko Adi. "Pertanggungjawaban Pidana Yang Memakai Surat Palsu Ditinjau dari Pasal 263 ayat (2) KUH Pidana", Jurnal Daulat Hukum, Program Magister (S2) Ilmu Hukum Fakultas Hukum Unissula, Semarang, Volume I, Nomor I, March 2018.

\section{Books:}

[1] Ediwarman. (2015). Monograf Metodologi Penelitian Hukum, Medan: Sofmedia.

[2] Hadikusuma, Hilman. (1995). Metode Pembuatan Kertas atau Skripsi Ilmu Hukum, Bandung : Mandar Maju. 
[3] Panggaribuan, Luhut M. P. (1996). Advokat dan Contemp of Court Satu Proses di Dewan Kehomatan Profesi, Jakarta: Djambatan.

[4] Rahardjo, Satjipto.(1976). Hukum Masyarakat dan Pembangunan, Bandung: Alumni.

[5] Soemitro, Ronny Hanitijo. (1990). Metode Penelitian Hukum dan Jurimetri, Jakarta: PT. Ghalia Indonesia.

[6] Soerjono Soekanto. (2011). Penelitian Hukum Normatif (Suatu Tinjauan Singkat), Jakarta: Rajawali Pers.

[7] Sugono, Bambang. (1996). Metodologi Penelitian Hukum, Jakarta: PT. Raja Grafindo Persada.

\section{Regulations:}

[1] Act No. 1 of 1946 concerning Criminal Law Regulations.

[2] Act No. 18 of 2003 concerning Advocates.

[3] Act No. 73 of 1958 concerning Declaring the Enactment of Act No. 1 of 1946 concerning Criminal Law Regulations for All Indonesia.

[4] Act No. 8 of 1981 concerning Criminal Procedure Law.

[5] Constitution of 1945 Republic of Indonesia.

[6] Criminal Code.

[7] Police Report Number: LP / B / 115B / XI / 2019 / Jabar 